\title{
青岛仰口榴辉岩中粒间柯石英 的发现及其意义*
}

\author{
叶 凯 (1) 平岛崇男 (2) 石渡明 ${ }^{(3)}$ 郭敬辉(1) 翟明国 (1) \\ (1)中国科学院地质研究所, 北京 100029 ; (2) 日本京都大学地质和矿物学系, \\ 日本京都 606-01; (3) 日本金泽大学地质系, 日本金泽 920)
}

\section{关镜词粒间柯石英 榴辉岩 青舟仰口}

柯石英是 $\mathrm{SiO}_{2}$ 的高压变种, 在 $700 \sim 800^{\circ} \mathrm{C}$ 时转变的压力是 $2.7 \sim 2.9 \mathrm{GPa}^{[1,2]}$, 因此柯石 英和柯石英假象是用来确认超高压变质作用的标志矿物. 到目前为止, 柯石英和柯石英假象 在西阿尔卑斯、挪威 Caledonides、哈萨克斯坦、德国和前捷克的 Saxonian Erzgebirge、波兰 Sneznik 山以及我国大别-苏鲁高压超变质带的榴辉岩及其他超高压变质岩中已有大量报 道 ${ }^{[3]}$. 这些柯石英多以单矿物包裹体的形式产出于石榴子石、绿辉石、蓝晶石、绿窝石、硬玉 甚至白云石、电气石、氟磷镁石、锆石和金刚石中 ${ }^{[3]}$. 柯石英的边缘常转化为棚状或细粒石英 集合体, 构成柯石英假象. 环绕柯石英及其假象, 主晶矿物常发育有放射状裂纹. Schertl 等 ${ }^{[4]}$ 发现在 Dora Maira 超高压镁铝榴石石英岩的基质中有许多类似柯石英假象的栅状石英 集合体, 有些沿镁铝榴石边缘的裂隙与包裹于镁铝榴石中的柯石英外缘的棚状石英集合体连 为一体, 从而证明了粒间柯石英存在的可能性,但真正的粒间柯石英从未有过报道.

最近我们在产于山东青岛仰口的榴辉岩中发现了真正的粒间柯石英, 这种榴辉岩呈不规 ·则饼状团块 $(2 \sim 30 \mathrm{~cm}) \times(2 \sim 30 \mathrm{~cm}) \times(0.5 \sim 3 \mathrm{~cm})$ 集合体, 产于超高压变质闪长岩或花岗闪 长岩中 ${ }^{[5]}$. 团块之间由白云母片岩胶结. 榴辉岩主要由细粒石榴子石、绿辉石、多硅白云母、 蓝晶石、䵢窝石和金红石组成, 它们多呈自形到半自形, 颗粒之间发育三节点. 岩石非常新鲜, 无退变质的迹象. 在石榴子石、绿辉石和蓝晶石中有大量柯石英包裹体. 粒间柯石英产于由 多颗石榴子石、绿辉石和蓝晶石所构成的空隙中, 其边缘常退变为栅状细粒石英集合体, 中心 仍保留有高凸起的柯石英(图 1,2), 电子探针分析显示它是纯的 $\mathrm{SiO}_{2}$ 相. 粒间柯石英周围的 矿物发育有大量以柯石英为中心的放射状裂纹. 该榴辉岩变质的温压条件类似于苏鲁超高压 变质带的其他柯石英榴辉岩 ${ }^{[5]}$.

粒间柯石英的发现很直观地证明柯石英并非晶内局部超高压条件下形成的, 而是独立的 超高压矿物相. 与之平衡共生的其他矿物, 如石榴子石、绿辉石、蓝晶石、䵢窝石和金红石等均 为超高压变质的产物. 柯石英及其他超高压矿物的保存取决于岩石退变的 $P-T$ 轨迹, 而 $P-T$ 轨迹是由以下因素决定的: 超高压岩石回返的速度、被俯冲岩块的大小、俯冲带的几何形

1995-12-08 收稿, 1996-03-01 收修改稿

* 国家自然科学基金资助项目 


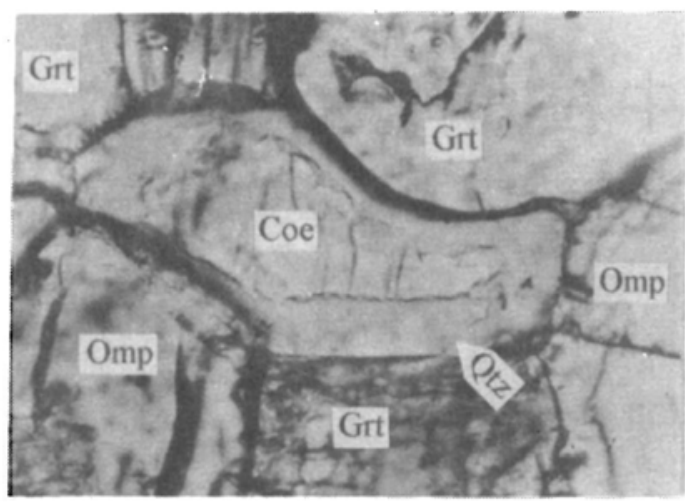

图 1 柯石英(Coe)产于多颗石榴子石(Grt) 和绿辉石 (Omp) 所构成的空隙中

其外缘已转变为棚状多晶石英集合体 ( $\mathrm{Qtz})$, 周围的 矿物发育有以柯石英为中心的放射状裂纹.

单偏光, $\times 160$

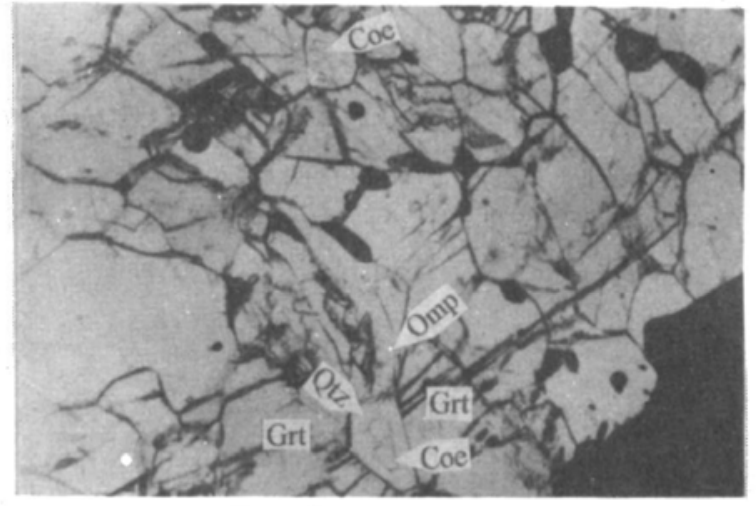

图 2 两颗粒间柯石英 $(\mathrm{Coe})$ 在同一视域内. 柯石 英产于多颗石榴子石 (Grt) 和绿辉石

(Omp) 所构成的空隙中

其外缘已转变为棚状多晶石英集合体 (Qtz), 周围的矿物 发育有以柯石英为中心的放射状裂纹. 单偏光, $\times 160$

态、流体参与的多少及速度、岩石的变形及超高压变质后的岩浆活动 ${ }^{[3]}$. 柯石英在后期变质 作用的影响下很容易退变为石英. 它的保存要求岩石以极快的速度 (大于 $10 \mathrm{~km} / \mathrm{a}^{[6]}$ ) 折返, 或有必要的压力容器使之免受后期温压条件变化的影响 ${ }^{[7]}$. 这也正是它们大多呈包裹体赋 存于石榴子石、绿辉石和蓝晶石等矿物中的原因. 尽管如此, 除了个别包裹于金刚石中的柯石 英没有任何退变之外 ${ }^{[8]}$, 在超高压变质岩中发现的柯石英的边缘均或多或少地退变为石英集 合 (柯石英假象). 仰口粒间柯石英的发现, 说明榴辉岩以非常快的速度由地下约 $100 \mathrm{~km}$ 的 深度回返到地表, 其速度绝非抬升和剥蚀机制所能满足的 ${ }^{[9]}$, 而要求快速的构造抬升机制.

\section{参考文献}

1 Bohlen S R, Boettcher A L. The quartz-coesite transformation: a pressure determination and the effects of other components. Journal of Geophysical Research, 1982, 87:7 073 7 078

2 Bose $\mathrm{K}$, Guanguly J. High pressure phase equilibria in the system $\mathrm{MgO}-\mathrm{SiO}_{2}-\mathrm{H}_{2} \mathrm{O}$ : quartz-coesite revisited and dehydration of talc. EOS, Transaction of the American Geophysical Union, 1992, 73: 618

3 Liou J G, Zhang R Y, Ernst W G. An introduction to ultrahigh-pressure metamorphism. The Island Arc, 1994, 3: 1 24

4 Schertl H P, Schreyer W, Chopin C. The pyrope-coesite rocks and their country rocks at Parigi, Dora Maira Massif, Western Alps: detailed petrography, mineral chemistry and PT-path. Contrib Mineral Petrol, 1991, 108: 1 21

5 Hirajima T, Wallis S R, Zhai M et al. Eclogitized metagranitoid from the Su-Lu ultra-high pressure (UHP) province, eastern China. Proceedings of the Japan Academy, 1993, 69(B): 249 254

6 Coleman R G, Wang X M eds. Overview of the geology and tectonics of UHPM. In: Ultrahigh-pressure metamorphism. New York: Cambridge University Press, 1994

7 Schreyer W. Subduction of continental crust to mantal depth: petrological evidence. Episodes, 1988, 11: 97 104

8 Jaques A L, Hall A E, Sheraton J et al. Composition of crystalline inclusions and C-isotope composition of Argyle, and Ellendale diamonds. Geol Soc America Special Pub, 1989, 14: 966 989

9 Platt J P. Exhumation of high-pressure rocks: a review of concepts and processes. Terra Nova, 1986, 5: 119 133 